\title{
Miasto późnośredniowieczne i nowożytne na przykładzie „Atlasu historycznego miast polskich - Gdańsk”
}

\section{Zofia Maciakowska}

Głównym celem „Atlasów historycznych miast” powstających pod patronatem Międzynarodowej Komisji Historii Miast jest stworzenie bazy źródłowej do badań nad procesami urbanizacyjnymi w Europie. W Polsce powstają one w trzech ośrodkach: w Toruniu - dla obszaru dawnych Prus Królewskich, Warmii, Kujaw i Mazur, pod redakcją naukową prof. dr. hab. Romana Czai ${ }^{1}$ (wcześniej prof. dr. hab. Antoniego Czacharowskiego); we Wrocławiu - dla Śląska, pod redakcją prof. dr hab. Marii Młynarskiej-Kaletynowej i dr. hab. Rafała Eysymontta, prof. UWr' ${ }^{2}$; w Krakowie - dla Małopolski, pod redakcją prof. dr. hab. Zdzisława Nogi ${ }^{3}$. Atlas historyczny Gdańska, przygotowany przez interdyscyplinarny zespół, powstał pod kierunkiem prof. dr. hab. Wiesława Długokęckiego z Uniwersytetu Gdańskiego ${ }^{4}$, a opublikowany zostanie w $2016 \mathrm{r}$.

Oprócz części tekstowej w „Atlasach” umieszczane są reprodukcje wybranych, rzadko publikowanych archiwalnych planów i wedut miast, a także plansze analityczne zawierające wyniki najnowszych badań i ustaleń dotyczących ich rozwoju przestrzennego. Jako podkład do wykonywania plansz wykorzystywany jest przerys najstarszej precyzyjnej mapy katastralnej. $\mathrm{Z}$ reguły przy tworzeniu „Atlasu” wykorzystywane są mapy pochodzące z 2. poł. XIX w. Nie są one wolne od błędów, lecz dla celów informacyjnych stwierdzone różnice nie mają więk-

1 Elbląg - 1993, Toruń - 1995, Bydgoszcz - 1997, Grudziądz - 1997, Giżycko - 1998, Chełmno - 1999, Malbork - 2002, Świecie - 2012 , Chojnice - 2013, 0stróda - 2014. Trwają prace nad atlasem Włocławka i Mragowa.

2 Wrocław - 2001; Niemcza, Środa Śląska, Trzebnica - 2003; Świdnica - 2008; Legnica - 2009; Ziębice - 2014. W 2015 r. ukaże się zeszyt Ząbkowic Śląskich.

3 Kraków - 2007, Sandomierz - 2014. Trwają prace nad atlasem Bochni.

4 Prace nad jego przygotowaniem finansowane były ze środków NCN, grant nr NN 108253 538. Opracowaniem objęty został obszar miasta w obrębie nowożytnych fortyfikacji. szego znaczenia. Zakres opracowań szczegółowych wyznaczony jest przez zasób materiałów źródłowych: pisanych i kartograficznych, a także stopień zaawansowania badań architektonicznych zachowanych budowli oraz badań archeologicznych na ich obszarze.

Te dwie ostatnie grupy źródeł odgrywają szczególnie istotną rolę przy odtwarzaniu układu nieruchomości w okresie średniowiecza i w nowożytności. W miastach o zachowanej zabudowie historycznej informacji na ten temat dostarczają przede wszystkim badania architektoniczne obiektów, zaś w miastach, w których uległa ona zniszczeniu - badania archeologiczne. Pozwalają one na w miarę jednoznaczne określenie pierwotnych podziałów własnościowych i późniejszych zmian, jednakże dysponują nimi badacze nielicznych miast ${ }^{5}$.

W ostatnich latach także w Gdańsku prowadzono badania archeologiczne kilku dużych kwartałów, jednakże wyniki prac nie zostały do tej pory opublikowane, co powoduje, że nie można było ich wykorzystać w celu przedstawienia zmian $\mathrm{w}$ parcelacji średniowiecznego miasta $^{6}$. Nie jest to niestety przypadek odosobniony, gdy ostateczne opracowanie wyników badań jest odsuwane w czasie. Obowiązujący w Polsce wymóg prowadzenia badań archeologicznych wyprzedzających działania inwestycyjne na obszarze miast miał na celu ochronę lub przynajmniej dokumentację pozostałości

\footnotetext{
5 Wykorzystywano je przede wszystkim w atlasach historycznych miast śląskich: Wrocławia, Niemczy, Trzebnicy, Świdnicy i Legnicy, a także Krakowa.

6 Badania kwartału położonego pomiędzy ulicami: Heweliusza, Gnilną i kościołem św. Bartłomieja (1996-1998); Rajską, Heweliusza, Kumstgasse (obecnie nieistniejącą) (1999-2000); Świętojańską, Szeroką, Pańską i Szklary (2000-2001, 2003-2004) (opublikowano wyniki z 2 pierwszych lat badań); Długi Targ, Powroźniczą, Ogarną (fragment) (2002-2003); Łagiewniki, Rybaki Górne, Heweliusza (2006); Szeroką, Świętojańską, Tandeta (2008).
} 
wcześniejszej zabudowy. W nowych warunkach ekonomicznych, w których inwestor dąży do zminimalizowania kosztów całej inwestycji, zazwyczaj przyjmowane są oferty najtańsze. W sytuacji dużej konkurencji na rynku badań archeologicznych prace wycenione są często tak nisko, że w ramach przewidzianej kwoty rzetelne przebadanie stanowiska i jego kompleksowe opracowanie nie jest możliwe. Choć ustawowo opracowanie takie powinno zostać napisane w ciągu 3 lat od ukończenia prac archeologicznych, rzadko kiedy rzeczywiście powstaje. Z punktu widzenia wiedzy o mieście są to badania zmarnowane, gdyż pozostają po nich tylko enigmatyczne sprawozdania przechowywane $\mathrm{w}$ archiwach odpowiednich urzędów konserwatorskich. Stanowisko wyczyszczone z zabytków - ruchomych, a często i nieruchomych - bez ostatecznego opracowania wyników badań staje się nieodwołalnie białą plamą na planie miasta (zabytki ruchome są przechowywane, ale ich opracowywanie z powodu braku środków odkładane jest zwykle „na później”). Do dyspozycji osób zainteresowanych śladami przekształceń układu miasta pozostają jedynie rysunki polowe, które dla przedstawicieli innych dyscyplin naukowych są nie do wykorzystania.

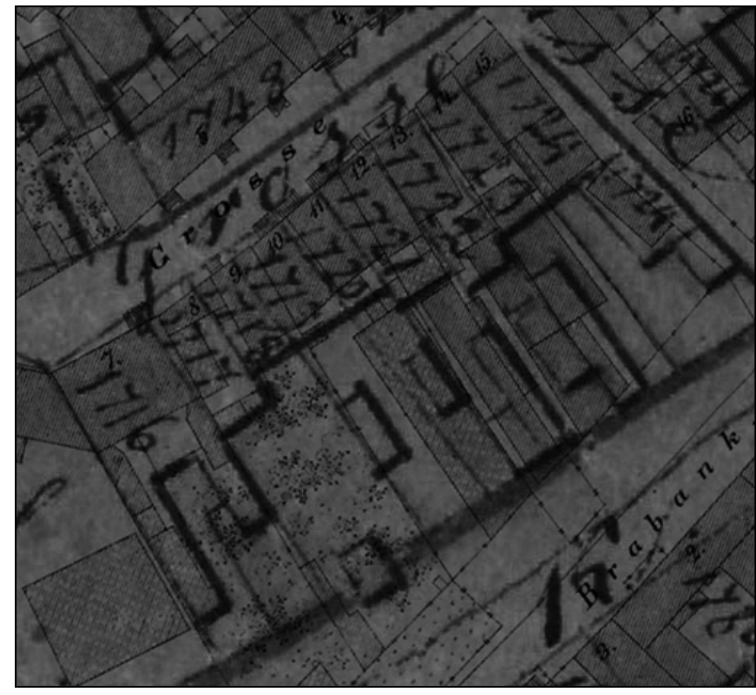

Ryc. 1. Fragment Wiadrowni. Nałożenie odpowiednio wyskalowanego planu z 1814 r. na plan katastralny Buhsego z lat 1866/1869. APG, 9,2/680; PAN Bibl. Gd. C/ 40.1
Podstawą do prowadzenia analiz zmian w układzie miejskim i prób odtworzenia parcelacji miasta w okresie średniowiecza są więc najczęściej archiwalne mapy i plany. Pierwszym zadaniem stojącym przed badaczem jest ocena ich wiarygodności i przydatności. Od ich przeznaczenia zależało bowiem, co i jak precyzyjnie było na nich przedstawione. Inaczej podchodzono do planów mających ukazać znaczenie miasta, w których skupiano się przede wszystkim na oddaniu jego formy i wskazaniu usytuowania obiektów municypalnych, sakralnych oraz układu miejskich fortyfikacji, inaczej zaś do tych tworzonych w związku z konkretnym zamówieniem, np. dla celów podatkowych, w których zasadniczą kwestią było określenie szerokości każdej posesji, czy też do planów miejskich umocnień, których forma miała decydujące znaczenie dla obronności miasta. W pierwszych planach katastralnych pochodzących z pocz. XIX w. jedynie w niewielkim stopniu przykładano wagę do precyzyjnego odzwierciedlenia formy i wielkości nieruchomości oraz stojącej na nich zabudowy. Nikt na podstawie tych planów nie mógł dochodzić swojej własności. Służyły one przede wszystkim celom informacyjnym, umożliwiając ocenę stopnia zagospodarowania obszaru miasta, obliczenie liczby działek i stojących na nich obiektów. Wyraźnie widać, że także układ ulic nie do końca odwzorowywał stan rzeczywisty. Zniekształcenia pomiędzy przeciwległymi krańcami miasta, jakie można stwierdzić, porównując je z katastrami pochodzącymi z 2. poł. XIX w. lub późniejszymi, sięgają nieraz kilkudziesięciu metrów. Przy ograniczeniu obszaru poddawanego analizie do jednej dzielnicy lub kwartału zazwyczaj okazuje się, że różnice pomiędzy nimi nie są aż tak duże, jak by to wynikało z nałożenia na siebie planów całych miast. Stąd pomimo pewnych wad wczesne plany katastralne stanowia doskonały materiał do badań nad zmianami przestrzennymi zachodzącymi na obszarze miasta od końca XVIII w., nie umożliwiają jednak precyzyjnego odtworzenia historycznej zabudowy w poszczególnych kwartałach. 
Wskazane - nazwijmy to - usterki planów powodują, że wiele problemów pojawia się przy opracowywaniu plansz obrazujących rozwój przestrzenny miasta, w których konieczne jest skorelowanie danych pochodzących z kilku planów. Ze względu na niedokładność wykonania nie można ich ze sobą porównać poprzez bezpośrednie odwzorowanie danych. Różnice w wielkościach i formach rysowanych obszarów lub obiektów są bowiem niekiedy bardzo znaczące, pomimo doprowadzenia ich do jednej skali. Przeniesienie wybranych informacji na planszę rozwoju miasta wymaga więc ich szczegółowej analizy i indywidualnego opracowania.

Problemy rozpoczynają się już w momencie podejmowania próby przeniesienia na odpowiednio przygotowany podkład (wykonany na bazie najstarszego planu katastralnego miasta) informacji dotyczących ukształtowania przestrzeni miejskiej, przedmieść i fortyfikacji. Dotyczy to także układu wodnego, który ulegał zazwyczaj dużym zmianom. Rzeki i potoki przez wieki zmieniały swoje koryta nie tylko w sposób naturalny, ale także na skutek działań człowieka. Najczęściej odtworzenie ich średniowiecznego przebiegu jest jedynie najbliższym możliwym tego przybliżeniem, a nie wierną rekonstrukcją. Do celów badawczych wykorzystywane są bowiem mapy powstałe dopiero w okresie nowożytnym. Uściślenie możliwe jest jedynie dzięki badaniom hydrogeologicznym, które jednak nie zawsze są dostępne.

Dużych trudności nastręcza także odtworzenie przebiegu i formy średniowiecznych fortyfikacji miasta, niezachowanych lub zachowanych częściowo w momencie wykonywania planu katastralnego stanowiącego podkład. Do dyspozycji pozostają często jedynie plany o dużym uproszczeniu, czasem miejskie weduty. W ustaleniu przebiegu obwarowań pomocne są materiały źródłowe, w których niekiedy opisane są bramy i baszty, ich liczba, a także poszczególne odcinki murów. Zdarza się, że usytuowanie baszt pozostaje jedynie hipotetyczne. Taka sytuacja ma miejsce w Gdańsku - we wschodniej części południowego odcinka murów Głównego Miasta.
Kwestia zakresu i przebiegu średniowiecznych obwarowań Starego Miasta i Starego Przedmieścia - choć istnieje kilka hipotez na ten temat do dziś pozostaje nierozstrzygnięta ${ }^{7}$. Znacznie prostsze jest odtworzenie formy fortyfikacji nowożytnych, które z reguły były wielokrotnie i w miarę precyzyjnie dokumentowane.

Niewątpliwie najtrudniejszym elementem badań nad przestrzenią średniowiecznego lub nowożytnego miasta jest próba korelacji źródeł pisanych $\mathrm{z}$ konkretnym miejscem $\mathrm{w}$ jego przestrzeni - $z$ odpowiednią nieruchomością. Uzyskiwane wyniki zależą przede wszystkim od rodzaju i kompletności źródeł, jakimi się dysponuje.

W Gdańsku nieocenionym materiałem, który można wykorzystać do badań nad topografią Głównego i Starego Miasta oraz przedmieść, są średniowieczne księgi gruntowe i czynszowe. Księgi gruntowe, a także niektóre spisy szosu, odmiennie niż w większości miast, prowadzone były w układzie topograficznym. Dla wpisywania właścicieli kolejnych działek przewidziane były w księgach odpowiednie miejsca. Specyfika prowadzenia ksiąg gruntowych polegająca na wycieraniu pumeksem nazwiska poprzedniego właściciela w chwili wpisywania nowego powoduje, że odnotowany w nich stan własnościowy odpowiada czasowi, w którym wychodzity one z użytku. Zachowały się cztery księgi gruntowe Głównego Miasta - zamykane w 1382, 1415, 1633 i 1814 r. $^{8}$, księgi Starego Miasta prowadzone do 1682 i 1814 r. ${ }^{9}$, Osieka - 1809 r. ${ }^{10}$, a także Starego Przedmieścia, przedmieść zachodnich, Wyspy Spichrzów - 1440, ok. 1640 i 1793 r. ${ }^{11}$, Wyspy Spichrzów z Długimi Ogrodami i Dolnym Miastem - 1814 r. ${ }^{12}$, Zamczyska, Wiadrowni i ul. Krosna - 1759 r. ${ }^{13}$

\footnotetext{
7 G. Bukal, Fortyfikacje Gdańska i ujścia Wisty 1454-1793, Sopot 2012, s. 41-44.

8 APG, 300,32/1, 300,32/2, 300,32/4-5, 300,32/11-12.

9 APG, 300,32/23, 300,32/27-30.

$10 \mathrm{APG}, 300,32 / 24$.

11 APG, 300,32/3, 300,32/7 (w tej księdze także Zamczysko, Wiadrownia i Brabank), 300,32/14-15. W księdze nr 14 znajdują się tylko przedmieścia zachodnie, a w księdze nr 15 - Stare Przedmieście, Wyspa Spichrzów i Ołowianka.

${ }_{12}$ APG, 300,32/16, Dolnego Miasta - 300,32/20 i 22.

13 APG, 300,32/19.
} 
Dla Głównego Miasta dysponujemy więc nazwiskami właścicieli działek w odstępach: 33, 218 i ok. 180 lat. Po przejęciu miasta przez Królestwo Pruskie w 1793 r., w momencie dokonywania na nieruchomościach pierwszej czynności prawnej po sprawdzeniu tytułu własności - którym zazwyczaj był dostarczany przez właściciela potwierdzony lub oryginalny odpis wpisu do dawnej księgi gruntowej - zakładano dla każdej z nich odrębną księgę gruntową ${ }^{14}$. W XIX w. przy prawie każdej z posesji do dawnych zbiorczych ksiąg gruntowych dopisano nazwy i numery kart tych nowych, indywidualnych ksiąg oraz numerację działek zgodną z regulacją z 1854 r. Pozwala to na powiązanie zapisów ówczesnych i pochodzących z nowożytnych ksiąg gruntowych. Przed wojną rozpoczęto korelację zapisów własności każdej z działek pochodzących z kolejnych nowożytnych ksiag gruntowych metodą retrogresywną, jednak wyniki tych prac nie zachowały $\operatorname{sie}^{15}$. Zastosowanie tej metody do ksiąg średniowiecznych nie jest niestety możliwe, gdyż liczba nieruchomości w poszczególnych odcinkach pierzei ulic w średniowieczu była inna w stosunku do stanu z okresu nowożytnego. Już pierwsze próby powiązania średniowiecznych spisów właścicieli z podziałami katastralnymi zanotowanymi w XIX w. kończą się więc niepowodzeniem.

$Z$ jeszcze trudniejszą sytuacją mamy do czynienia w przypadku Starego Przedmieścia i przedmieść zachodnich. Nieład wpisów powoduje, że zatarciu uległy nie tylko najstarsze zapisy; niemożliwa do odtworzenia pozostaje też sekwencja nazwisk właścicieli przypisanych do kolejnych nieruchomości. W przypadku tych ksiąg do wykorzystania w badaniach nad topografią miasta pozostają jedynie nazwy ulic lub nazwy przypisane następującym po sobie fragmentom spisów w obrębie podmiejskiej przestrzeni pozwalające na zorientowanie się w zasięgu zasiedlenia w momencie zakładania i zamykania ksiąg. Nie zawsze jasne pozostaje

14 Zachowane księgi i akta gruntowe znajdują się w zbiorach AP Gdańsk, Oddział w Gdyni, zespół nr 98.

15 E. Kloss, Gdańskie ksieggi gruntowe, „Archeion”, 22, 1954, s. 196-198. jednak odniesienie do konkretnego miejsca na mapie miasta niektórych wpisów określających ulice lub okolice miasta, których brak na najstarszych planach ${ }^{16}$.

W badaniach nad średniowieczną parcelacją miasta istotne znaczenie ma określenie czasu, w którym nastąiło ustalenie granic wyznaczające okres utrwalenia się podziałów własnościowych. W centralnej części Gdańska miało to miejsce dopiero na przełomie XIV i XV w. Zabudowa murowana w poślednich częściach miasta i na przedmieściach - na Nowym Mieście, Starym Przedmieściu, Długich Ogrodach i wąskich, równoległych do Motławy ulicach bocznych Głównego Miasta - powstała często dopiero w XVII w., ostatecznie zamykając okres formowania się układu własnościowego Głównego Miasta. Najstarsze plany katastralne w jakimś stopniu odzwierciedlają układ tego właśnie czasu. Jak proces ten przebiegał na obszarze Starego Miasta, nie daje się prześledzić ze względu na niezachowanie się jego średniowiecznych ksiąg gruntowych. Dla tego okresu dysponujemy zaledwie dwoma późnymi spisami szosu, które umożliwiają jedynie podjęcie próby odtworzenia zmian w zasiedleniu obszaru miasta, do jakich doszło w przeciągu XV w.

Pomimo zachowania się średniowiecznych i nowożytnych ksiąg gruntowych Głównego Miasta i nowożytnych ksiąg staromiejskich korelacja pomiędzy kolejnymi księgami nie jest więc prosta.

$\mathrm{Na}$ podobne trudności natrafiają badacze $\mathrm{w}$ większości miast ${ }^{17}$. Odtworzenie średniowiecznej parcelacji bez odpowiednich badań archeologicznych czy architektonicznych nie jest możliwe ${ }^{18}$. Przy ich braku część badaczy zajmujących się analizą przekształceń prze-

16 Problem ten dotyczy przede wszystkim przedmieść zachodnich, gdyż w księgach ujęto nieruchomości znajdujące się zarówno w obrębie fortyfikacji, jak i poza nimi.

17 Zob. M. Goliński, Przy wrocławskim rynku. Rekonstrukcja dziejów własności posesji. Część 1: 1345-1420, Wrocław 2011, s. 12-14.

18 Zdarza się, że badania archeologiczne nie przynoszą rozstrzygnięcia na temat pierwszego rozmierzenia miasta. W Elblagu okazało się, że pomimo przeprowadzenia badań szerokopłaszczyznowych (przebadano $8700 \mathrm{~m}^{2}$ ) odtworzenie XIII-wiecznej parcelacji miasta nie jest możliwe ze względu na procesy łączenia i rozpadu pierwotnych działek 
strzeni miast korzysta z metody analizy metrologicznej, szczególnie popularnej w latach 60. i 70. XX w. ${ }^{19}$ Zakłada ona, że miasta średniowieczne rozmierzane były według planu modularnego, w którym działki mieszczańskie miały powtarzalne rozmiary ${ }^{20}$. Dowodem na słuszność tych założeń miały być wielkości działek wskazywane w przywilejach lokacyjnych miast. Podawane przede wszystkim w celach podatkowych, nie stanowią one jednak bezpośredniej dyspozycji co do podziału przestrzeni miasta. Jak wynika z szeregu zachowanych dokumentów, na jego obszarze występowały także działki o wielkościach innych niż tzw. lokacyjna, odnotowana źródłowo ${ }^{21}$.

Zastosowanie tej metody, po ustaleniu wielkości tzw. działki lokacyjnej, miało pozwolić na odtworzenie średniowiecznej struktury miasta i prześledzenie zachodzących $\mathrm{w}$ nim zmian. Może ona przynosić zadowalające rezultaty w miastach małych, powstałych na surowym korzeniu, których założona $\mathrm{w}$ średniowieczu wielkość okazała się trwała, a zmiany w wielkościach nieruchomości polegały jedynie na łączeniu lub rozpadzie pierwotnych działek. $\mathrm{Z}$ inną sytuacją mamy do czynienia w miastach

oraz zniszczenie śladów pierwszej zabudowy i podziałów przez zabudowę murowaną. G. Nawrolska, Problemy badań zespołów miejskich na przykładzie Elbląga, w: 750 lat praw miejskich Elbląga. Księga pamiątkowa, red. A. Groth, Gdańsk 1996, s. 104. Na ten temat zob. także P. Konczewski, Działki mieszczańskie w południowo-wschodniej części średniowiecznego i wczesnośredniowiecznego Wrocławia, „Wratislavia Antiqua”, 9, 2007, s. 27, 41.

19 Metodę tę w badaniach miast, w których nie dysponowano wynikami odpowiednich badań architektonicznych lub archeologicznych, wykorzystywali przede wszystkim Tadeusz Kozaczewski, Tadeusz Zagrodzki i Janusz Pudełko, a ostatnio Bogusław Krasnowolski. Obszerna literatura tematu: E. Kierzkowska-Kalinowska, W kwestii badań nad rozplanowaniem miasta średniowiecznego, „Kwartalnik Historii Kultury Materialnej", 23 (1), 1975, s. 119-120; S. Gawlas, Ulica a zmiany krajobrazu miejskiego w okresie lokacji, „Kwartalnik Historii Kultury Materialnej", 47, 1-2, 1999, s. 3-4.

${ }^{20}$ S. Gawlas zwrócił uwagę na fakt, że analizy te „dotyczą raczej w pełni już wykształconego programu miasta lokacyjnego. [...] Ważnym elementem kwestionowanych konstrukcji interpretacyjnych jest nieudowodnione przekonanie o istnieniu geometrycznego, blokowego modelu przestrzennego lokacji miejskiej już od początku tego procesu". S. Gawlas, Ulica a zmiany, s. 4.

21 W. Schich, Zur Grösse der Area in den Gründungsstädten im Östlichen Mitteleuropa nach den Aussagen der schriftlichen Quellen, w: Studien zu mittelalterlichen Quellen, Hrsg. S. Jenks, J. Sarowsky, M.-L. Laudage, Köln-Wien-Weimar 1993, s. 81-115; P. Konczewski, Działki mieszczańskie, s. 41. dużych, których rozwój w okresie średniowiecza poprzedzającym wzniesienie murów ogniowych był bardzo dynamiczny. Tu do zmian wielkości działek od czasu ich rozmierzenia do momentu ostatecznego ustalenia granic dochodziło wielokrotnie. Nie wszystkie linie graniczne uwzględnione na planach katastralnych odpowiadają więc pierwotnym granicom, co praktycznie uniemożliwia traktowanie ich jako jedynej podstawy do badań. Problemem jest także przeniesienie dzisiejszych pomiarów na system miar średniowiecznych ${ }^{22}$. Ponadto, jak zauważył Winfried Schich, posługiwanie się metodą metrologiczną nie przynosi w pełni wiarygodnych rezultatów, gdyż analizy wykonywane są na bazie dość schematycznych planów $^{23}$.

Pomijając kwestię trwałości pierwszych granic, trzeba pamiętać, że w analizach korzysta się z podkładów wykonywanych maksymalnie

22 Przy braku odpowiednich źródeł pisanych badacze podejmują niekiedy próby odtworzenia wielkości pierwotnych miar na podstawie przeliczeń szerokości bloków zabudowy lub nieruchomości rekonstruowanych jako początkowe miasta lokacyjnego. Prace prowadzone są w oparciu 0 analizy XIX- lub XX-wiecznych planów katastralnych. Zob. J. Pudetko, Dziatka lokacyjna w strukturze przestrzennej średniowiecznych miast śląskich XIII wieku, „Kwartalnik Architektury i Urbanistyki”, 9 (2), 1964, s. 117-118, 130-131; B. Krasnowolski, Lokacyjne układy urbanistyczne na obszarze ziemi krakowskiej w XIII i XIV wieku, Kraków 2004, s. 137-140, 183-185. Ustalenia metrologiczne odnośnie do miar stosowanych przy rozmierzeniach Krakowa poddawał w wątpliwość Mateusz Goliński. M. Goliński, Wokót socjotopografii późnośredniowiecznej Świdnicy, cz. 1, Wrocław 2000, s. 85. Zob. także tenże, Socjotopografia późnośredniowiecznego Wrocławia, Wrocław 1997, s. 10-15.

W Gdańsku miarą nowochełmińską (w okresie nowożytnym zwaną gdańską) posługiwano się od czasów średniowiecza aż do wprowadzenia stopy reńskiej w końcu XVIII w. Przez cały ten czas starano się utrzymać jej pierwotny wymiar. W 1747 r. podjęto próbę określenia wielkości stopy używanej w XVII-wiecznym Gdańsku w stosunku do stopy paryskiej. M. Hanow, Preussische Landesordnung wegen der Maasse und Gewichte, vom Jahre 1307 mit Erläuterungen, w: Preussische Sammlung, Bd. 1, Danzig 1747, s. 468-491. Ustalono wówczas (po współczesnym przeliczeniu na miary metryczne), że wynosita ona $29,2 \mathrm{~cm}$. Ponieważ uważano (pogląd zakwestionowany przez Hanowa), że 81 ówczesnym stopom gdańskim odpowiadało 80 stóp nowochełmińskich, wielkość stopy nowochełmińskiej można by dziś określić na $29,02 \mathrm{~cm}$. W przeliczeniach względem stopy paryskiej z 1778 r. stopa gdańska miałaby natomiast wynosić dziś 28,66 cm. G. Kruenitz, Oekonomische Encyclopaedie oder allgemeines System der Staats-, Stadt-, Haus- u. Landwirtschaft in alphabetische Ordnung, T. 15, Berlin 1778, s. 519.

23 W. Schich, Zur Grösse der Area, s. 108. Kwestie dokładności map w zależności od skali, w jakiej zostały wykonane, przeanalizował Janusz Pudełko. J. Pudełko, Próba pomiarowej metody badania planów niektórych miast średniowiecznych w oparciu o zagadnienia dziatki, „Kwartalnik Architektury i Urbanistyki”, 9 (1), 1964, s. 6. 
w skali 1:500. Kreska planu o grubości 0,3 mm odpowiada wtedy $15 \mathrm{~cm}$ rzeczywistej wielkości, a przy częściej stosowanej skali 1:1000-30 cm, a więc mniej więcej długości cegły. Wątpliwości budzi też wiarygodność wyznaczania na podkładzie katastralnym granicy nieruchomości w zwartej zabudowie pierzei ulicznej. Jeśli XIX-wieczny geodeta przy sporządzaniu pierwszej precyzyjnej mapy opierał się na wskazaniach właścicieli, to czy mieli oni świadomość, gdzie pierwotnie owa granica przebiegała? ${ }^{24}$

Ze źródeł wiadomo, że w sytuacji gdy sąsiedzi nie byli w stanie równocześnie podołać kosztom budowy muru, linia graniczna bywała często przesuwana w stosunku do granicy pierwotnej działki ${ }^{25}$. Czasem następowało to przez zajęcie gruntu sąsiada (np. w Krako$w_{i e^{26}}$ ), a czasem - jak zdarzało się niekiedy w Gdańsku - przez oszczędne, minimalistyczne budowanie muru na granicy od jego strony. W gdańskich księgach gruntowych istnieje zapis mówiący o tym, że właściciel nieruchomości może skorzystać $\mathrm{z}$ muru zbudowanego na granicy działki przez jego sąsiada, aby umieścić w nim końcówki belek wznoszonego przez siebie domu ${ }^{27}$. Jak z tego wynika, musiało

24 Na wątpliwości w tej kwestii wskazują liczne ekspertyzy mistrzów rzemiosł budowlanych. W księgach oględzin cechowych budynków zachowała się ekspertyza wykonana przez starszych cechów 10 stycznia 1690 r.: „Daß die Mauer nach Anweisung des grossen Vorhauses vermöge der Scheide-Wandt (so durchgebohret) auf die halbe Scheide Wandt zeiget und die Maure alleine auf besagten Herr Constantin Schützen Grunde stehet, und dessen Gebäude eintzig und alleine zu Gutte aufgeführet worden". APG, 300 C/2083, s. 233. Jak wynika z treści ekspertyzy, była ona wykonywana z powodu niemożności ustalenia, do kogo mur należał (a więc na czyjej działce się znajdował). W innym przypadku po wykonaniu wiercenia ustalono, że z muru ogniowego 0 grubości 27 cali, 18 cali należało do jednego, a 9 cali do drugiego z sąsiadów. Tamże, s. 17. Wydaje się, że wskazówką do ustalenia podziału mogła być oś muru granicznego, o ile taki istniał. Tamże, s. 157.

25 Na ten temat obszernie w J. Pudełko, Próba pomiarowej, s. 9-11.

26 Tamże, s. 10, 20

27 APG, 300,32/4, k. 88a. Claus Brun zezwala Johannowi Amelungowi na osadzenie belek w należącym do niego murze granicznym. Pełne prawo do korzystania z muru otrzyma dopiero po spłaceniu połowy kosztów jego budowy. Podobnie APG, 300 C/2083, s. 278. Jednakowy obustronny sposób murowania ściany ogniowej był wskazaniem do uznania muru za wspólną własność obu sąsiadów podczas oględzin budowlanych w 1641 r. APG 300 C/2083, s. 21: , Schließlich befinden wir, daß beyde Parten zu offtgemeldter Brandmawr fug und recht haben und ihnen beyden derselbe zustehe[t], alldieweil solches obgmeldt[es] auf beyden Seyten verhande[nes] Blindwerk und Absätze außweisen". Podobne stwierdzenie zob. tamże, s. 126 brakować w nim zwyczajowych odsadzek do ich oparcia, a więc mur był od tej strony węższy. W takim przypadku linia graniczna byłaby zgodna z pierwotną (oś muru ogniowego

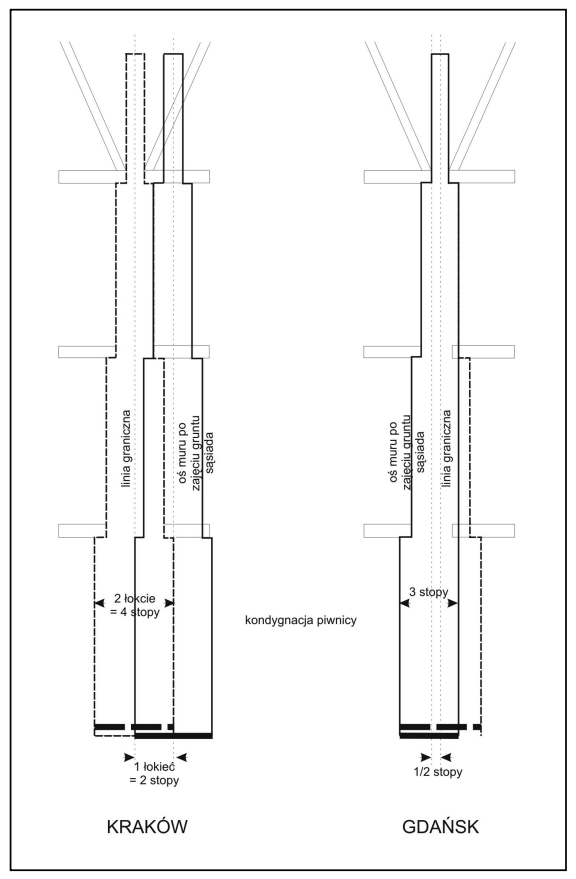

Ryc. 2. Schemat przesunięcia osi muru granicznego w sytuacji, kiedy jeden z sąsiadów nie był w stanie podołać kosztom jego budowy

o grubości 1 cegły wyniesionego na wysokość 7 stóp ponad kosz dachu, by się z nią pokrywała), lecz geometryczny środek dolnej części muru o grubości 3,5 cegły uległby przesunięciu o grubość jednej lub połowy cegły, a więc $15-30 \mathrm{~cm}$. Podobnie byłoby w sytuacji jednostronnego obmurowania ścian przez jednego z sąsiadów. Sytuacje tego typu zdarzały się w okresie nowożytnym - w ten sposób przygotowywano oparcie dla sklepień, wzmacniano ściany o niepewnej konstrukcji lub niwelowano ich wychylenie ${ }^{28}$. Tym samym dokonywano

\footnotetext{
28 Sytuacja taka została potwierdzona w badaniach architektonicznych Domu Uphagena przy ul. Długiej 12, gdzie pogrubiono ściany piwniczne w momencie wykonywania sklepień, a jednocześnie obmurowano ścianę z dekoracją wnękową w sieni. A. Piwek, J. Tarnacki, Inwentaryzacja i badania ścian piwnic „Domu Uphagena” w Gdańsku, ul. Długa 12,
}

\section{Studia Geohistorica • Nr 03.2015}


przesunięcia geometrycznego środka ściany. Jest to sytuacja niewidoczna dla oczu osoby wykonującej obmiary geodezyjne, możliwa do stwierdzenia dopiero po wykonaniu pomiarów wewnętrznych. Jeśli nie dysponuje się wynikami badań archeologicznych lub architektonicznych pozwalających na określenie formy i struktury muru ogniowego, płotu czy muru wygradzającego tylną część działki, ustalenie tych granic nie jest możliwe, a co za tym idzie, wątpliwe są wyniki poszukiwania wiarygodnej powtarzalnej szerokości nieruchomości ${ }^{29}$.

Przy braku badań jednoznacznie rozstrzygających o średniowiecznej parcelacji wszelkie próby przypisania informacji źródłowych do konkretnych działek są więc tylko hipotetyczne. Nawet w przypadku dwóch wąskich sąsiadujących ze sobą nieruchomości nie możemy mieć pewności, że powstały w wyniku podziału jednej większej posesji lub też że wyjątkowo duża działka jest efektem połączenia co najmniej dwóch. Upewniają nas o tym zapisy z najstarszej gdańskiej księgi gruntowej, założonej w 1357 r., z których wiele dotyczyło wielkości działek. Część z nich pochodzi z tego właśnie czasu. Księgą objęto tereny Nowego Miasta, położone na północ od starszej części Głównego Miasta, przyłączone po 1342 r. Jak wskazują wyniki badań archeologicznych, ich zagospodarowanie nastąpiło jednak dopiero w 2. poł. lat 40. XIV w. Zapisy księgi gruntowej pochodzą więc $\mathrm{z}$ czasu zaledwie o ok. 10 lat późniejszego niż rozpoczęcie działań inwestycyjnych na tym terenie. Praktycznie są

Gdańsk 1993 (mps), s. 6, 11; ciż, Badania architektoniczne sien "Domu Uphagena" w Gdańsku, Gdańsk 1995 (mps); Z. Maciakowska, Dom Uphagena - próba podsumowania stanu badań, w: Mieszczaństwo gdańskie, red. S. Salmonowicz, Gdańsk 1997, s. 102.

29 Rozwarstwienia ścian domu dokonano np. przy ul. Szklary 1. Z. Polak, Wyniki wstępnej analizy reliktów zabudowy zachodniej pierzei ulicy Szklary, w: Dominikańskie Centrum Św. Jacka, red. A. Gołembnik, t. 2 Warszawa 2002, s. 23, 30-31.

Janusz Pudełko opracował własną metodę określania prawdopodobnej szerokości pierwotnie wytyczonych działek, która pomimo ewentualnych przesunięć granic, do których mogło dojść na przestrzeni wieków pozwala na wyłonienie ich szerokości na podstawie analiz metrycznych. Opisał ją w następujący sposób: „Metoda, jaką posłużyłem się do zbadania wymiarów działki pierwotnie wytyczonej, składa się w zasadzie z dwu części: pomiaru szerokości wszystkich działek w zespole rynkowym, wyłonienia grupy względnie grup najczęściej powtarzają-

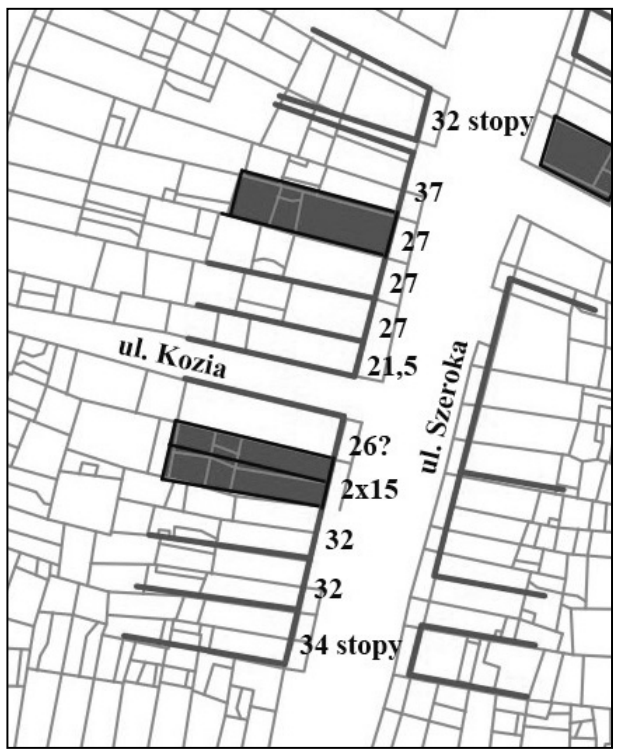

Ryc 3. Fragment przerysu planu Buhsego z lat 1866-1869 obejmujacy potudniową pierzeje ul. Szerokiej na odcinku pomiędzy ul. Grobla I a Weglarską, na którym zaznaczono szerokości lub powierzchnię dziatek opisanych w I księdze gruntowej Głównego Miasta założonej w 1357 r.

więc równoczasowe. Dają one niezwykle cenną możliwość wglądu w rzeczywisty sposób rozdysponowania przestrzeni miasta.

Zestawienie oryginalnych zapisów dotyczących wielkości działek pozwala stwierdzić, że brak wśród nich wielkości powtarzalnych (wielokrotnościami sznura są natomiast poszczególne odcinki pierzei ulic). Występują zarówno działki piętnasto-, dwudziesto- i dwudziestokilku-, trzydziesto- i trzydziestokilkustopowe.

cych się szerokości działek, następnie po przeliczeniu tego wymiaru na stopy o wielkości stosowanej w średniowieczu na Śląsku zbadanie, jaki związek może mieć najczęściej powtarzająca się szerokość działki z ewentualną szerokością pierwotnie wytyczoną, posługując się analogią z wymiarami działek znanymi ze średniowiecznych przekazów pisanych. Część drugą stanowiła graficzna kontrola, polegająca na wrysowaniu w bloki zabudowy mieszkaniowej na planie miasta dziatek o znalezionych wymiarach i sprawdzenie, w jakim stopniu odpowiednie wymiary bloków są wielokrotnością odpowiednich wymiarów znalezionej działki". J. Pudełko, Działka lokacyjna, s. 117. W metodzie stosowanej przez Janusza Pudełkę i jego kontynuatorów zakładano, że początkowo szerokości wszystkich działek pierzei były jednakowe. Wszelkie odstępstwa od wielkości wyłonionej w badaniach traktowane były jako efekt późniejszych przesunięć wynikających z zajmowania gruntu sąsiada. Nie brano pod uwagę możliwości zróżnicowania już na etapie rozmierzania działek. 


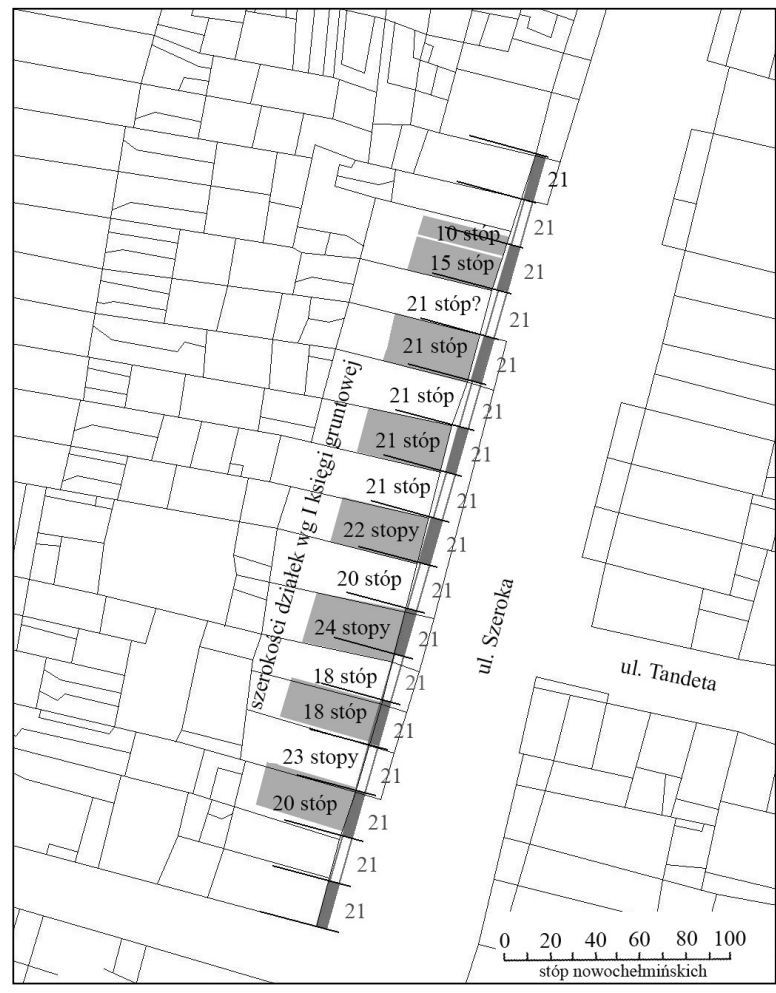

W późniejszym okresie zapisano nawet rozmiary sześćdziesięciostopowe. W niektórych przypadkach w miejscu wielkości podawano "hereditas", jego połowę lub półtora, tak jakby pod tym określeniem kryła się konkretna wielkość. Być może nazwę tę należy odnieść do dokumentu z 1352 r., w którym podano wysokość czynszu, który mógł być wykupiony od działki o wielkości $2 \times 7$ prętów (ok. $8,6 \times 30,1 \mathrm{~m})^{30}$. Na całym obszarze Nowego Miasta liczącym 376 działek, dla którego zachowały się opisy wielkości 133 parcel, określonych tak zostało tylko 15 - w większości przy ul. Straganiarskiej ${ }^{31}$.

Analiza tych zapisów zdaje się wskazywać, że wbrew dość powszechnej opinii o istnieniu tzw. działki normatywnej czy lokacyjnej nie występowała ona w gdańskim Nowym Mie-

30 P. Simson, Geschichte der Stadt Danzig, Bd. 4, Danzig 1918, nr 87. 31 Z. Maciakowska, Ksztaftowanie przestrzeni, s. 77-81, aneksy 3-4.

32 Mateusz Goliński zwracał uwage na fakt, że jest to pogląd rozpowszechniony wśród urbanistów. M. Goliński, Wokót socjotopografii,

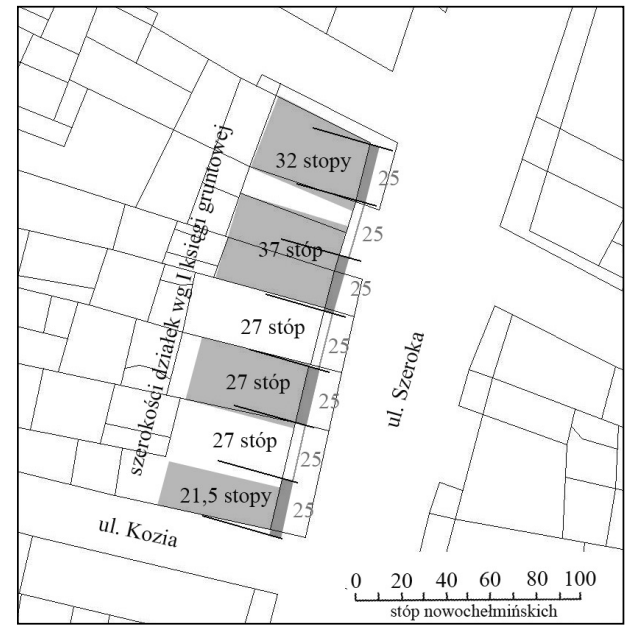

Ryc. 4. Dwa fragmenty przerysu planu Buhsego z lat 1866-1869, na którym zaznaczono szerokość działek wg I księgi gruntowej Głównego Miasta założonej w 1357 r. oraz schemat modularnego podziału pierzei wynikający $z$ analizy szerokości nieruchomości w celu znalezienia wielkości normatywnej. Bez informacji źródłowych otrzymana wielkość mogłaby się stać podstawą do uznania jej za pierwotną, a wszelkie odstępstwa od niej - za efekt późniejszych przesunięć granic

ście ${ }^{32}$. Jedynie w niektórych odcinkach pierzei można wyłonić sekwencje kilku jednakowych wymiarów, np. przy ul. Szerokiej - pomiędzy ul. Grobla I a Przędzalniczą (21 stóp). Jak można się jednak przekonać, kolejne nieruchomości miały już szerokości nieznacznie od nich odbiegające. Nie wiadomo, co spowodowało to zróżnicowanie. Należy raczej odrzucić możliwość istnienia na tym terenie wcześniejszej trwałej zabudowy, gdyż mury ogniowe w centralnej części gdańskiego Głównego Miasta pojawiły się dopiero na przełomie XIV i XV w. Wynikało to więc zapewne $\mathrm{z}$ decyzji podejmowanych na etapie rozmierzenia działek. Trudno stwierdzić, czy było to specyfiką miejsca objętego zasiedleniem, odległego od centrum czy też wynikało z późnego zagospodarowania tej części miasta. Jest to jednak przestroga przed

s. 79, 81. Jako niewyjaśnioną wskazał także kwestię występowania jedynie pełnych działek w pierwszym etapie rozmierzenia Krakowa. Tamże, s. 82-83. 
bezkrytycznym korzystaniem z metody metrologicznej. Wydaje się, że modularne podziały kwartałów zabudowy możliwe były jedynie w małych miastach, w dużych natomiast ograniczone były do strefy przyrynkowej ${ }^{33}$. Były one także uzależnione od warunków terenowych, obrysu miasta i ewentualnych pozostałości wcześniejszego zagospodarowania tere$\mathrm{nu}^{34}$. Być może wielkość wytyczanych działek zależała od rodzaju rzemiosła, jakim parali się ich właściciele. Inna musiała być bowiem działka tkacza lub sukiennika, a inna szewca. Nie wiadomo też, w jaki sposób kontrolowano proces podziału nieruchomości w określonej pierzei. Najprościej byłoby, gdyby rozmierzenie i sprzedaż działek rozpoczynano od narożników bloku, w miarę zainteresowania kupujących postępując w kierunku środka pierzei. Dzięki temu można by uniknąć sytuacji, w której ostatnia z działek byłaby zbyt wąska lub zbyt szeroka na budowę wygodnego domu. Moje zastrzeżenia co do powszechności stosowania modularnej parcelacji przestrzeni wewnątrzblokowej nie odnoszą się do wprowadzania modularnych podziałów przestrzeni miasta siatką ulic w okresie średniowiecza, wynikających z wykorzystywania wypróbowanych wzorców rozmierzania. Ich stosowanie ułatwiało organizację przestrzeni miejskiej.

Przy braku wiarygodnych danych na temat średniowiecznej parcelacji badanego ośrodka niezwykle trudno powiązać informacje źródłowe $\mathrm{z}$ przestrzenią miasta. Rzadko kiedy dysponuje się wystarczająco dokładnym opisem usytuowania działki, pozwalającym na jednoznaczne przypisanie do niej zapiski ${ }^{35}$. $\mathrm{Z}$ jednej strony wynika to $\mathrm{z}$ lakonicznego charakteru adnotacji urzędowych, z drugiej zaś - ze wspomnianego już braku zgodności pomiędzy liczbą parcel uwidocznionych na XIX-wiecznych planach katastralnych a liczbą

\footnotetext{
33 Jest to pogląd prezentowany przez większość badaczy zajmujących się przekształceniami przestrzeni miejskiej w średniowieczu.

${ }_{34} \mathrm{Na}$ ten temat na podstawie wyników badań archeologicznych zob. P. Konczewski, Działki mieszczańskie, s. 38-41.

35 Zwracał na to uwagę prof. Mateusz Goliński w swojej książce poświęconej właścicielom działek przyrynkowych we Wrocławiu, Przy wrocławskim rynku, s. 12-14.
}

właścicieli w poszczególnych odcinkach ulic odnotowanych w księgach gruntowych czy czynszowych. Najczęściej dysponuje się - i to po żmudnych badaniach źródłowych - spisem właścicieli pierzei usystematyzowanych w ciągu sąsiedzkim. Przykładem mogą tu być badania prof. Mateusza Golińskiego dla Wrocławia $^{36}$. W Gdańsku pewnym udogodnieniem przy próbach korelacji jest występowanie w niektórych kwartałach działek rozciągających się pomiędzy dwiema ulicami. Pozwala to na sytuowanie działek należących do tego samego właściciela w układzie liniowym, co do pewnego stopnia porządkuje układ nieruchomości w obrębie kwartału; nie daje jednak całkowitej pewności co do właściwej rekonstrukcji rozmieszczenia działek. $Z$ taką sytuacją w Gdańsku mamy do czynienia w zasadzie jedynie w blokach położonych pomiędzy ul. Długą, Długim Targiem a ul. Ogarną ${ }^{37}$. Przy badaniach innych kwartałów jest się właściwie bezradnym - nawet w przypadku korzystania z metody retrogresywnej. Korelacja danych z ksiąg gruntowych, które wyszły z użytku w 1415 i 1633 r. - a więc zawierają nazwiska właścicieli działek odnotowanych w odstępie prawie 200 lat - jest praktycznie niemożliwa.

Tak się składa, że dwóm głównomiejskim księgom gruntowym zamykanym w 1382 i 1415 r. ${ }^{38}$ odpowiadają spisy szosu z $1377 / 1378$, ok. 1380, 1385 i 1416 r. ${ }^{39}$ Powiązanie informacji ze średniowiecznych ksiąg gruntowych i spisów szosu pozwoliło na opracowanie częściowej socjotopografii Głównego Miasta w Gdańsku ok. $1380 \mathrm{r} .^{40}$ Obejmowała ona dwie grupy - patrycjat i niektóre cechy rzemieślnicze. W przypadku patrycjatu (po określeniu pewnych generalnych zasad, jakimi się posłużono przy rozstrzyganiu, która z nieruchomości należących do tej samej osoby stanowiła jego miejsce zamieszkania) udało się wskazać nieruchomości,

\footnotetext{
36 Tamże.

37 Z. Maciakowska, Ksztattowanie przestrzeni, s. 73-75.

38 APG, 300,32/1, 300,32/2.

39 E. Keyser, Die Bevölkerung Danzigs und Ihre Herkunft im 13. und 14. Jahrhundert, Lübeck 1924 (Pfingstblätter des hansichen Geschichtsvereins, 15); APG, 300, 12/395, 300,12/396.

40 Z. Maciakowska, Ksztaftowanie przestrzeni, s. 36-38, 96-102.
} 


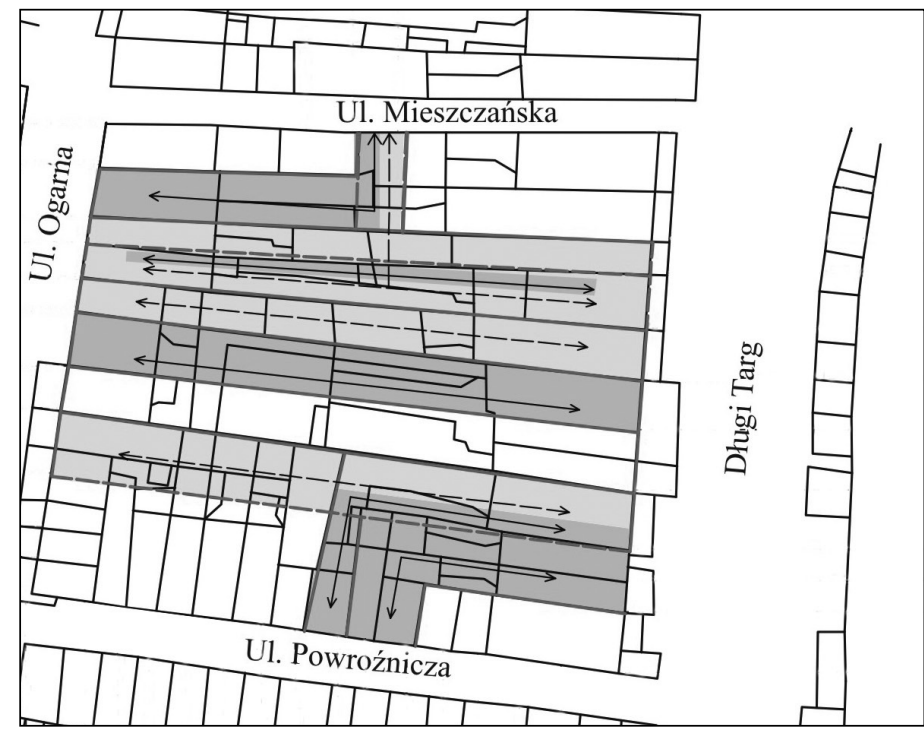

Ryc. 5. Schemat powiązań działek położonych przy równolegtych i prostopadtych do siebie ulicach. Kolorem jaśniejszym oznaczono działki należące do jednego właściciela wg zapisów I księgi gruntowej, a więc stanu z 1382 r.; ciemniejszym - te wg zapisów II księgi, stan z 1415 r.

które stanowiły siedzibę rodzinną oraz te, które były przeznaczone na wynajem lub uprawianie rzemiosła. Ustalenie miejsc zamieszkania i usytuowania warsztatów rzemieślniczych było nieco bardziej skomplikowane. Spis szosu z lat 1377/1378, wykonany także w układzie topograficznym, obejmował znaczną grupę mieszkańców miasta; nie wszyscy w nim wymienieni byli właścicielami nieruchomości. Niekiedy kilka osób objętych szosem nosiło te same imiona i nazwiska; powtarzały się one także wśród rzemieślników należących do różnych cechów. Stąd powiązanie osób objętych spisem z konkretnym miejscem w mieście obarczone było pewnym błędem. Trudności z odtworzeniem parcelacji średniowiecznej spowodowały, że jako podkład do wykonania plansz socjotopograficznych wykorzystano plan z zaznaczoną siatką ulic, bez podziałów na działki. Nie można było bowiem w sposób w pełni odpowiedzialny wskazać precyzyjnego usytuowania nieruchomości, z którymi były związane poszczególne osoby. Lokalizację miejsc zamieszkania wskazano więc jedynie w przybliżeniu, co dla celów badawczych było wystarczające, gdyż pozwalało na waloryzację poszczególnych rejonów miasta $^{41}$. W tym czasie najbardziej prestiżową część Gdańska tworzyły ulice Ogarna z Długą i Długim Targiem. Obszar Nowego Miasta, położony na północ od ul. Szerokiej, pozostawał poza zainteresowaniem najzamożniejszych. Skupiska rzemieślników jednej profesji występowały przy niektórych ulicach: kaletników i paśników przy Kaletniczej, tkaczy przy Tkackiej, garbarzy przy Garbarach, szewców w pierzei południowej początkowego fragmentu ul. Długiej i przy ul. Dzianej, skrzyniarzy przy ul. Tokarskiej, browarników i słodowników przy ul. Ogarnej (dawnej Browarnej), Piwnej-Chlebnickiej, Szerokiej i Straganiarskiej. Rzemiosła budowlane zajęły posesje położone na wschód od klasztoru dominikańskiego, pomiędzy klasztorem a kościołem Mariackim.

Równie trudne było ustalenie lokalizacji targów, obiektów handlowych i przemysłowych (poza ogólnie znanymi), gdyż rzadko odnotowywano je w księgach gruntowych. Wiele z nich nie przetrwało do czasów nowożytnych, stąd próżno ich szukać na najstarszych planach, a dotyczące ich informacje pochodzą

41 Tamże, s. 96-102. 
bardzo często z przywilejów związanych z ich użytkowaniem lub z kontraktów ich dzierżawy przez osoby prywatne od władz miejskich (nowożytność). Jeśli ich lokalizacja bywała określana, to jedynie w sposób ogólny - w odniesieniu do dzielnicy czy ulicy, przy której się znajdowały. Stanowiło to znaczne utrudnienie przy ich oznaczaniu na planszy. Niekiedy, nie mogąc tego zweryfikować, przyjmowano lokalizację wskazywaną przez wcześniejszych badaczy lub zgodną z XIX-wiecznymi adnotacjami w księgach gruntowych identyfikującymi ich usytuowanie ${ }^{42}$.

Podobne problemy występowały także przy próbach odtworzenia topografii miasta nowożytnego. Na planach nowożytnych zaznaczano bowiem jedynie najbardziej znaczące budowle miejskie, pomijając inne należące do kamlarii, oddawane w dzierżawę za czynsz. Usytuowanie niektórych z nich udało się ustalić dzięki informacjom topograficznym zawartym w opisach obiektów będących przedmiotem dzierżawy ${ }^{43}$. Lokalizację innych - choć wiadomo, że na określonym obszarze występowały, np. ramy sukiennicze i farbiarskie na Zamczysku - można było wskazać jedynie w sposób ogólny ${ }^{44}$. Wiele nowych ustaleń udało się natomiast poczynić w kwestii zagospodarowania terenów przyłączonych do miasta na skutek budowy nowych fortyfikacji w XVII w. Było to możliwe dzięki zachowaniu się bogatych materiałów źródłowych $\mathrm{z}$ tego czasu $-\mathrm{z}$ jednej strony planów pochodzących z 2. poł. XVII i XVIII w., z drugiej zapisów w odpowiednich księgach gruntowych i czynszowych. Pozwolity one na ustalenie czasu wytyczania nowych ulic i ich zasiedlania.

${ }^{42}$ Np. szlifiernia przy ul. Podwale Staromiejskie. APG, 300,32/23, k. 20b.

${ }^{43} \mathrm{~Np}$. kuźnia srebra Hansa von der Rennena znajdować się miała „Aufm Alten Schlosse, beyme Waßergraben an der Mawr der Motlaw [...]". APG, 300,12/226, s. 196. „[...] aufm Alten Schloß am Fischmarckte [...]". APG, 300,12/373, s. 204. Lokalizację tego zakładu przybliża także plan sytuacyjny z $1667 \mathrm{r}$. APG, 300MP/39.

${ }^{4} \mathrm{~Np}$. APG, 300,12/373, s. 120: „5. Tuchrämen im Graben aufm Alten Schloße [...]”; s. 122: „[...] die Rahmen auf dem Alten Schloße [...]”; s. 124: „[...] ein Hauß und Färberey aufm Alten Schloße mit 5. Tuchrämen [...]”; s. 126: „[...] ein Gebewde und Färberey auffm Alten Schloße, mit 3 Tuchrämen [...]”; tamże: „[. . . die vorderste Färberey auf dem Alten Schloße, sambt dem Platz kegenüber darauf vier Tuchrämen stehen [...]".
Z braku odpowiednich źródeł (wczesnonowożytne spisy, w tym księgi gruntowe nie zawierały informacji o profesji poszczególnych osób) nie można było jednak opracować socjotopografii wczesnonowożytnego miasta.

Spis mieszkańców, w którym podano profesję osób zamieszkujących w gdańskich domach (niekiedy zawody pomijano), istnieje dopiero dla 1770 r. ${ }^{45}$ Wykonany był w związku z poszukiwaniem poddanych króla pruskiego ukrywających się w Gdańsku. Jego wykorzystanie do badań nad socjotopografią miasta jest jednak utrudnione. Pomimo zachowania się prawie pełnego spisu nie są znane zasady jego wykonywania w obrębie każdej z ulic, stąd występują trudności w powiązaniu osób z konkretną nieruchomością ${ }^{46}$. W oparciu o spis możliwe jest jedynie statystyczne przedstawienie struktury zawodowej mieszkańców poszczególnych ulic miasta lub ich fragmentów ${ }^{47}$. Kolejny spis, z 1797 r., przybliża natomiast jedynie miejsca zamieszkania kupiectwa gdańskiego, członków garnizonu gdańskiego, urzędników różnego typu instytucji (w tym miejskich i państwowych), osób związanych z kościołami, szpitala$\mathrm{mi}$, a także pełniących funkcje społeczne ${ }^{48}$.

Pełną informację o właścicielach nieruchomości (bez imion) na terenie Starego i Głównego Miasta oraz Starego Przedmieścia przynosi spis zakwaterowań żołnierzy francuskich w domach mieszczańskich z lat 1807-1809 ${ }^{49}$, znajdują się w nim bowiem informacje o profesji właścicieli. Objął on 2098 posesji z obszaru Głównego Miasta, 487 ze Starego Przedmieścia i 1348 ze Starego Miasta. Jego uzupełnieniem jest spis opłat na utrzymanie latarni

45 Fragment dotyczący Starego Miasta został opublikowany: A. Groth, K. Wanta, J. Włodarski, Ein Einwohnerverzeichnis der Stadt Danzig aus dem Jahre 1770, w: Sonderdruck aus „Altpreußische Geschlechtskunde”, Bd. 30, Jg. 48, Hamburg 2000.

$46 \mathrm{Na}$ ten temat zob. E. Łączyńska, Mieszkańcy ul. Szerokiej w świetle spisu z 1770 roku, w: Studia i materiały do dziejów domu gdańskiego, red. E. Kizik, cz. 2, Gdańsk-Warszawa 2011, s. 183-217.

47 Po uzupełnieniu danych na temat zawodu właścicieli domów z innych źródeł. Tamże, s. 190.

48 Adreßbuch der Königl. West- Preußischen See- und Handelsstadt Danzig und der combinierten Städte Stolzenberg furs Jahr 1797, Danzig 1797.

${ }^{49}$ APG, 300,18/131, 300,18/132. Część imion można ustalić w oparciu 0 zapisy ksiąg gruntowych. 
z terenu Długich Ogrodów ze 136 pozycjami ${ }^{50}$, co daje w sumie 4069 nieruchomości. Spisem nie objęto niestety Dolnego Miasta i przedmieść zachodnich. Dzięki jego opracowaniu i analizie możliwe było wykonanie socjotopografii miasta w tym czasie. Do tego celu konieczna była m.in. korelacja numerów serwisowych nieruchomości używanych w spisie z numerami nadanymi im w 1854 r. Podczas jej wykonywania okazało się, że niektóre posesje wymieniane na pocz. XIX w. w połowie tego stulecia już nie istniały. Czasem było to odnotowane w spisie adresowym z 1854 r. (jeśli na przykład zostały połączone $\mathrm{w}$ jedną parcelę z sąsiednią) $)^{51}$, jednak zdarzało się, że były w nim zupełnie pominięte. Problemem było też odnalezienie ich na planie miasta. Najstarszy jego plan katastralny pochodzi z 1814 r. $^{52}$, a więc już z czasów po zniszczeniach powstałych podczas oblężeń z 1807 i 1813 r. Posesje wypalone pozostawiono na nim bez przebiegu granic i bez opisania ich numerami. W takich przypadkach nie było możliwe odtworzenie rzeczywistych podziałów parcelacyjnych. Rysowane na planszy rozgraniczenia miały więc charakter umowny, umożliwiający pokazanie ciągu sąsiedzkiego. W niektórych miejscach - szczególnie na obszarze Osieka, Zamczyska i Wiadrowni - pomimo oznaczenia numerami trudno było odnieść podziały nieruchomości z planu z $1814 \mathrm{r}$. do widocznych na podkładzie z lat 1866-186953. Na wcześniejszym planie zaznaczone były bowiem w sposób bardzo uproszczony, a usytuowanie wynikające z zapisów w księdze adresowej w żadnej mierze do planu nie przystawało. W związku z tym w szeregu miejsc przypisanie informacji o zawodzie właściciela do konkretnej nieruchomości na planszy socjotopografii z lat 1807/1809, choć było

50 GStA PK Berlin, II HA, Westpreussen und Netzedistrikt, Abt. 9, Städte: Danzig (Varia), nr 102, k. 9b-12a.

${ }^{51}$ Allgemeiner Wohnungs-Anzeiger für Danzig und dessen Vorstädte auf das Jahr 1854, Danzig 1854; Verzeichniß der Grundstücke in der Stadt, und zwar innerhalb der Rechtstadt, Altstadt, Vorstadt, Niederstadt und Außenwerke zusammengestellt nach der alten und neuen Servis-Nummern, Danzig 1854

$52 \mathrm{APG}, 9,2 / 680$.

53 Jako podkład wykorzystano przerysowany plan Buhsego z lat 18661869. PAN Bibl. Gd., C I 40.1 poprzedzone wnikliwymi analizami wszystkich dostępnych materiałów kartograficznych, może być obarczone pewnym błędem. Przy wykonywaniu planszy socjotopografii z $1854 \mathrm{r}$. problemów tych już nie było.

Dużym zaskoczeniem dla prowadzących badania było stwierdzenie, że u progu XIX $\mathrm{w}$. zarówno na Głównym, jak i na Starym Mieście w Gdańsku wiele ulic lub ich fragmentów nadal, jak w średniowieczu, zasiedlonych było przez przedstawicieli jednego cechu. Oba miasta różniły się także w charakterze, co wynikało z osiedlania się na ich obszarze odmiennych grup zawodowych. W czasie kiedy wykonywano spis, podział na Główne i Stare Miasto był nadal wyraźnie zaznaczony w strukturze miasta. O tym, jak wyglądało rozlokowywanie się przedstawicieli różnych zawodów na obszarze miasta, decydowało kilka czynników. Pierwszy, jaki należy wskazać, to tradycja miejsca, w którym od średniowiecza prowadzona była działalność określonej grupy rzemieślniczej. Przy liczącej 20 posesji ul. Kaletniczej, zamieszkałej w średniowieczu przez kaletników i paśników, mieszkało w tym czasie 7 kaletników i szewców. Przy liczącej 34 działki ul. Złotników 12 stanowiło własność przedstawicieli tego cechu. Jej południowy, usytuowany bliżej kościoła fragment zajęli szewcy, zajmujący zapewne wcześniej działki przy ul. Szewskiej - po przeciwnej stronie ul. Św. Ducha. Nieruchomości posiadało tu aż 13 osób; tylko jeden szewc pozostał przy ul. Szewskiej. Przy ul. Bednarskiej i w jej najbliższej okolicy mieszkało 20 bednarzy. Podane liczby odnoszą się do właścicieli działek i nie uwzględniają osób, które mogły zamieszkiwać w budynkach znajdujących się na posesji.

Do grupy innych czynników mających wpływ na osiedlanie się przedstawicieli różnych zawodów można zaliczyć położenie wybranego przez nich miejsca w przestrzeni miejskiej. Centrum Głównego Miasta zamieszkiwali więc nadal kupcy, maklerzy oraz urzędnicy miejscy. Nad Motławą w rejonie ujścia Raduni 88 osób osiadłych na niewielkim obszarze związanych było zawodowo z pobliską stocznią i z żeglugą lub uprawiało rybołówstwo. 
Nie mniej istotne było występowanie odpowiednich warunków zewnętrznych do uprawiania określonego rzemiosła - np. dostęp do otwartej wody i łatwość odprowadzenia ścieków poprodukcyjnych. Nad dawnymi północnymi fosami Głównego Miasta i w pobliżu Jatek Staromiejkkich osiadło 28 rzeźników (położone tu grunty otrzymali od rady Głównego Miasta w zamian za działkę dawnej rzeźni). W sąsiedztwie znalazły się także 23 nieruchomości garbarzy.

Pięćdziesiąt lat później ślady średniowiecznej struktury zasiedlenia uległy w znacznym stopniu zatarciu. Nadal trwało natomiast zróżnicowanie w zamożności ludności zamieszkującej Główne i Stare Miasto. W dalszym ciągu handlowym centrum Gdańska pozostawały centralne ulice Głównego Miasta.

W niniejszym artykule starałam się zaakcentować te elementy pracy nad zmieniającą się topografią miasta, które przysparzają badaczom najwięcej problemów. Nie dotyczą one tylko badań nad Gdańskiem, ale mają charakter bardziej ogólny. Pokazują ograniczenia wynikające ze stanu badań i zachowania źródeł, na jakie natrafia się podczas analiz rozwoju przestrzennego miast. Chciałam także wskazać te dziedziny, w których pomimo tworzenia nowych metod badawczych nadal nie uzyskujemy satysfakcjonującego wyniku. Mam tu na myśli przede wszystkim badania nad średniowieczną parcelacją miast. Być może kiedyś uda się znaleźć metodę wiarygodnego powiązania źródeł pisanych (w tym przede wszystkim spisów szosu) z wielkościami zanotowanymi na najstarszych planach katastralnych i odkrytymi w ba- daniach archeologicznych. Moje doświadczenia w badaniach nad miejską przestrzenią Gdańska pokazują bowiem, że badania metrologiczne nie zawsze przynoszą wiarygodne rezultaty.

Zdaję sobie sprawę z tego, że poruszyłam jedynie niektóre tematy warte szerszego omówienia. Dzięki temu, że badaniem przestrzeni miejskiej zajmują się przedstawiciele różnych dyscyplin naukowych, mamy szansę na wymianę doświadczeń i przemyśleń - możemy rozwijać swoje pomysły z wykorzystaniem możliwości warsztatowych innych dziedzin. Możemy je też weryfikować, zestawiając $\mathrm{z}$ informacjami uzyskanymi od innych badaczy. Ciągle uczymy się, jak łączyć ze sobą materiały pochodzące z różnych źródeł, aby przyniosły jak najwięcej informacji na temat zmian w przestrzeni miejskiej, gdyż czasem z korelacji niewielkich, wydawałoby się oderwanych od siebie wzmianek, wyłania się obraz jakiegoś miejsca lub obiektu, o którym pamięć zaginęła lub któremu nie można było przypisać konkretnego miejsca na planie miasta. Wykonywanie plansz - niezbędnego elementu atlasów - uczy nas też dyscypliny, która przy słownym opisywaniu przestrzeni nie musi być tak rygorystycznie przestrzegana. Wielokrotnie podczas przygotowywania plansz topograficznych zmieniałam sposób rysowania i linię średniowiecznych fortyfikacji miasta, przesuwałam punkty symbolizujące usytuowanie obiektów przemysłowych. Wahałam się, wyznaczając obrys placów targowych. Postawienie kropki czy kreski na planie jest jednoznacznym określeniem lokalizacji obiektu czy przebiegu granic. Warto o tym pamiętać. 


\section{Bibliografia}

Źródła archiwalne

APG, 300,32/1-5, 7, 11, 14, 15-16, 19-20, 22-24, 27-30.

APG, 300 C/2083.

APG, 300,12/226, 373, 395-396.

APG, 300,18/131-132.

APG, 300MP/39.

Źródła wydane drukiem

Adreßbuch der Königl. West-Preußischen See-und Handelsstadt Danzig und der combinierten Städte Stolzenberg furs Jahr 1797, Danzig 1797.

Allgemeiner Wohnungs-Anzeiger für Danzig und dessen Vorstädte auf das Jahr 1854, Danzig 1854.

Hanow M., Preussische Landesordnung wegen der Maasse und Gewichte, vom Jahre 1307 mit Erläuterungen, w: Preussische Sammlung, Bd. 1, Danzig 1747.

\section{Literatura przedmiotu (najważniejsze pozycje)}

„Atlas historyczny miast polskich”, t. 1: Elblag, red. A. Czacharowski, Toruń 1993; Toruń, red. A. Czacharowski, Toruń 1995; Chetmno, red. A. Czacharowski, Toruń 1999; Grudziąd, red. A. Czacharowski, Toruń 1997; Malbork, red. A. Czacharowski, R. Czaja, Toruń 2002; Świecie, red. R. Czaja, Toruń 2012; Chojnice, red. R. Czaja, Toruń 2013; t. 2: Bydgoszcz, red. A. Czacharowski, Toruń 1997; t. 3: Gizycko, red. A. Czacharowski, Toruń 1998; t. 4: Wroctaw, red. M. Młynarska-Kaletynowa, Wrocław 2001; Środa Śla$s k a$, red. M. Młynarska-Kaletynowa, Wrocław 2002; Trzebnica, red. M. Młynarska-Kaletynowa, Wrocław 2003; Niemcza, red. M. Młynarska-Kaletynowa, Wrocław 2003; Świdnica, red. M. Młynarska-Kaletynowa, Wrocław 2008; Legnica, red. M. Młynarska-Kaletynowa, Wrocław 2009; Ziębice, red. M. Młynarska-Kaletynowa, Toruń 2014; t. 5: Kraków, red. Z. Noga, Kraków 2007; Sandomierz, red. Z. Noga, Sandomierz 2014.

Bukal G., Fortyfikacje Gdańska i ujścia Wisty 1454-1793, Sopot 2012.
APG, 9,2/680.

GStA PK Berlin, II HA, Westpreussen und Netzedistrikt, Abt. 9, Städte: Danzig (Varia), nr 102.

PAN Bibl. Gd., C I 40.1.

Kruenitz G., Oekonomische Encyclopaedie oder allgemeines System der Staats-, Stadt-, Hausu. Landwirtschaft in alphabetische Ordnung, T. 15, Berlin 1778.

Simson P., Geschichte der Stadt Danzig, Bd. 4, Danzig 1918.

Verzeichniß der Grundstücke in der Stadt, und zwar innerhalb der Rechtstadt, Altstadt, Vorstadt, Niederstadt und Außenwerke zusammengestellt nach der alten und neuen Servis-Nummern, Danzig 1854.

Chorowska M., Lasota C., Rekonstrukcja uktadu dziatek $w$ blokach przyrynkowych we Wroctawiu, „Kwartalnik Historii Kultury Materialnej", 43 (3), 1995.

Ciemnołoński J., Massalski R., Stankiewicz J., Notatki o odkryciach architektonicznych na terenie Gdańska, „Rocznik Gdański”, 14, 1955.

Czaja R., Socjotopografia miasta Elblaga w średniowieczu, Toruń 1992.

Dunin-Wąsowiczowa A., Uwarunkowanie pomiarowe ksztattu i wielkości średniowiecznych placów miejskich, „Kwartalnik Historii Kultury Materialnej”, 40 (3), 1992.

Eysymontt R., Pierzeje uliczne $w$ miastach ślaskich, „Kwartalnik Historii Kultury Materialnej”, 47 (1-2), 1999.

Eysymontt R., Średniowieczne lokacje Ślaska europejskie inspiracje, wzory i podobieństwa, w: Procesy lokacyjne miast $w$ Europie Srodkowo-Wschodniej, red. C. Buśko, M. Goliński, B. Krukiewicz, Wrocław 2006.

Gawlas S., Ulica a zmiany krajobrazu miejskiego w okresie lokacji, „Kwartalnik Historii Kultury Materialnej”, 47 (1-2), 1999. 
Golińnki M., Dziatka miejska w ślaskich źródtach pisanych (XIII-XIV w.), „Kwartalnik Historii Kultury Materialnej”, 43 (3), 1995.

Goliński M., Przy wroctawskim rynku. Rekonstrukcja dziejów wtasności posesji. Część 1: 1345-1420, Wrocław 2011.

Goliński M., Socjotopografia późnośredniowiecznego Wroctawia, Wrocław 1997.

Goliński M., Wokót socjotopografii późnośredniowiecznej Świdnicy, Wrocław 2000.

Gołembnik A. i in., Wstepne opracowanie stanowiska, sezon 2002 r., Gdańsk „Hotel Rezydent”. Wykopaliska archeologiczne, cz. 1-2, 2004 (mps PWKZ).

Groth A., Wanta K., Włodarski J., Ein Einwohnerverzeichnis der Stadt Danzig aus dem Jahre 1770, w: Sonderdruck aus "Altpreußische Geschlechtskunde", Bd. 30, Jg. 48, Hamburg 2000.

Hammel-Kiesow R., Wege zur Erforschung städtischer Häuser und Höfe, Beiträge zur fächerübergreifenden Zusammenarbeit im Spätmittelalter und in der frühen Neuzeit, Neumünster 1993.

Kąsinowski A., Średniowieczna kamienica mieszczańska: Elblag, Ryga, Kotobrzeg, w: Stare miasto $w$ Elblagu - wyzwanie historii. Materiaty $z$ konferencji naukowej poświęconej pamięci Tadeusza Nawrolskiego, Elbląg 1997, s. 81-89 (Archeologia Elbingensis, 2).

Keyser P., Die Bevölkerung Danzigs und Ihre Herkunft im 13. und 14. Jahrhundert, Lübeck 1924 (Pfingstblätter des hansichen Geschichtsvereins, 15).

Kierzkowska-Kalinowska E., W kwestii badań nad rozplanowaniem miasta średniowiecznego, „Kwartalnik Historii Kultury Materialnej”, 23 (1), 1975.

Kloss E., Gdańskie ksieggi gruntowe, „Archeion”, 22, 1954.

Kochanowski M., $Z$ problematyki odkryć archeologicznych w obrębie Wielkiego Mtyna w Gdańsku, w: Gdańsk średniowieczny w świetle najnowszych badań archeologicznych $i$ historycznych, Gdańsk 1998.

Konczewski P., Dziatki mieszczańskie w potudniowo-wschodniej części średniowiecznego i wczesnośredniowiecznego Wroctawia, „Wratislavia Antiqua", 9, 2007.
Kozaczewski T., Rozplanowanie, uktad przestrzenny i rozwój miasta średniowiecznego, Wrocław 1973 (Prace Naukowe Instytutu Historii Architektury, Sztuki i Techniki Politechniki Wrocławskiej, 5).

Krasnowolski B., Lokacyjne uktady urbanistyczne na obszarze ziemi krakowskiej w XIII i XIV wieku, Kraków 2004.

Łączyńska E., Mieszkańcy ul. Szerokiej w świetle spisu z 1770 roku, w: Studia i materiaty do dziejów domu gdańskiego, red. E. Kizik, cz. 2, Gdańsk-Warszawa 2011.

Maciakowska Z., Ksztattowanie przestrzeni miejskiej Gtównego Miasta w Gdańsku do początku XV wieku, Gdańsk 2011.

Maciakowska Z., Szymański W., Akta Policji Budowlanej jako materiat do studiów nad gdańska kamienica mieszczańskq od średniowiecza do początku XIX wieku, w: Dom w miescie sredniowiecznym i nowożtnym, Wrocław 2004.

Maciejewski T., Zbiory wilkierzy $w$ miastach państwa zakonnego do 1454 r. i Prus Królewskich lokowanych na prawie chetmińskim, Gdańsk 1989.

Nawrolska G., Problemy badań zespotów miejskich na przyktadzie Elblaga, w: 750 lat praw miejskich Elblaga. Ksiega pamiatkowa, red. A. Groth, Gdańsk 1996.

Polak Z., Sprawozdanie z prac archeologicznych prowadzonych w 2003 roku $w$ Gdańsku na obszarze parceli Dtugi Targ 19 (stanowisko „Hotel Rezydent”) w zwiazku z rozbiórka hotelu "Jantar", 2004 (mps PWKZ).

Polak Z., Wyniki wstępnej analizy reliktów zabudowy zachodniej pierzei ulicy Szklary, w: Dominikańskie Centrum Św. Jacka, red. A. Gołembnik, t. 2, Warszawa 2002.

Polak Z., Zabudowa mieszkalna i gospodarcza. Typy konstrukcji, przemiany przestrzenne, datowanie, w: Archeologia średniowiecznego Kotobrzegu, red. M. Rębkowski, Kołobrzeg 1999.

Pudełko J., Dziatka lokacyjna w strukturze przestrzennej średniowiecznych miast ślaskich XIII wieku, „Kwartalnik Architektury i Urbanistyki”, 9 (2), 1964.

Pudełko J., Próba pomiarowej metody badania planów niektórych miast średniowiecznych 
w oparciu o zagadnienia dziatki, „Kwartalnik Architektury i Urbanistyki”, 9 (1), 1964.

Schich W., Zur Grösse der Area in den Gründungsstädten im Östlichen Mitteleuropa nach den Aussagen der schriftlichen Quellen, w: Studien zu mittelalterlichen Quellen, Hrsg. S. Jenks, J. Sarowsky, M.-L. Laudage, Köln-Wien-Weimar 1993.

Sowina U., Średniowieczna dziatka miejska w świetle źródet pisanych, „Kwartalnik Historii Kultury Materialnej”, 3, 1995.

Urbańczyk P., Plac miejski - skutek czy warunek powstania miasta?, „Kwartalnik Historii Kultury Materialnej”, 3, 1992.

Witthöft H., Rute, Elle und Schuh in Preußen. Zur Struktur der Längen- und Flächenmaße seit dem 13. Jahrhundert, „Scripta Mercaturae", 15 (1), 1981.
Zagrodzki T., Regularny plan miasta średniowiecznego a limitacja miernicza, Wrocław 1962 (Studia Wczesnośredniowieczne, 5, 1).

Zagrodzki T., Zagadnienie proporcji w uktadach urbanistycznych niektórych miast pomorskich, „Studia Pomorskie”, 1, 1957.

Zagrodzki T., Ze studiów nad tradycjami rzymskiej limitacji mierniczej wśredniowieczu. Plan Starego Miasta w Toruniu, „Zapiski Historyczne", 40 (1), 1975.

Zarębska T., Badania historyczno-urbanistyczne. Metoda analiz przestrzennych, „Kwartalnik Historii Kultury Materialnej”, 43 (1), 1995.

Zobolewicz J., Rozplanowanie Starego Miasta $w$ Toruniu $w$ świetle analizy metrologicznej, „Rocznik Toruński”, 10, 1975.

\section{A Late Medieval and Early Modern Town: the Case of "Historical Atlas of Polish Towns - Gdańsk"}

\section{Summary}

In the present article the author attempted to present the problems experienced while working on the changing city topography. These are the reflections the sources of which were the studies conducted in the course of preparing a historical atlas of Gdańsk (supervised by Professor Doctor Habilitated Wiesław Długokęcki, University of Gdańsk).

Results of the research are above all connected with the state of research (source studies, archeological and architectural studies) and the maintenance of sources. When these are insufficient, it frequently turns out that an unambiguous presentation of the spatial development is not possible.

One of the basic sources to analyze the changes in the urban arrangement and to attempt to recreate the city subdivision in the medieval period are the archival maps and plans. Transferring selected information on the board of the city development requires a detailed analysis and an individual approach. Considerable problems are connected with recreating the city fortifications and their forms which are not preserved or which were preserved only partially at the moment when the oldest cadastral plan was prepared, the basis of most boards. However, the most difficult element of research on the space of a medieval or modern town is certainly an attempt at correlating the written sources with a specific place in its space - with a specific estate. This requires reconstruction of the town subdivision, which - with a lack of proper archeological or architectural studies is not possible. Some researchers who deal with the analysis of transformations of the urban space make use of the method of metrological analysis, which was particularly popular in the 1960's and the 1970's and according to which medieval towns were measured in accordance with the modular plan. Results of research conducted for the New Town in Gdańsk question 
the application of this method separately from the sources unambiguously determining the medieval subdivision. In case of no such sources any attempts to ascribe the source information to concrete plots are only hypothetical.

Similar difficulties also occur while establishing the localization of markets, trading and industrial places - besides those that are generally well-known. Many of them have not survived till modern times and that is the reason why they cannot be found on the oldest plans. The graphic presentation of the localization of those and other places or areas and their borders requires considerable discipline from researchers which does not have to be so rigorously observed in the verbal description of the space.

An interesting observation made while transferring the source materials to the city plan was that at the beginning of the $19^{\text {th }} \mathrm{c}$. a number of streets or their fragments both in the Main and the Old Town in Gdańsk were still settled by representatives of one guild, like it was in the Middle Ages. Both towns had different character, which resulted from the settlement of different professional groups in their areas.

Słowa kluczowe: atlas historyczny miast polskich, rozwój przestrzenny, średniowiecze, działka, miasto, socjotopografia

Keywords: historical atlas of Polish towns, spatial development, Middle Ages, a plot of land, town, sociotopography

dr Zofia Maciakowska - adiunkt w Pracowni Historii Gdańska i Dziejów Morskich Polski w Instytucie Historii im. Tadeusza Manteuffla Polskiej Akademii Nauk (e-mail: zofiam@poczta.onet.eu) 